\title{
Implementasi Sistem Tertanam Pada Papan Ketik untuk Meningkatkan Penyaringan Konten Porno Melalui Pencarian Kata pada Browser
}

\author{
Bachtiar Lazuardi ${ }^{1}$, Hartanto Kusuma Wardana ${ }^{2}$, Deddy Susilo ${ }^{3}$ \\ 1,3Program Studi Teknik Elektro, \\ Fakultas Teknik Elektronika dan Komputer, \\ Universitas Kristen Satya Wacana, Salatiga \\ 1bachtiarlazuardi@gmail.com, ${ }^{3}$ deddy.susilo@uksw.edu \\ ${ }^{2}$ Program Studi Teknik Komputer, \\ Fakultas Teknik Elektronika dan Komputer, \\ Universitas Kristen Satya Wacana, Salatiga \\ hartanto.kusuma@uksw.edu
}

\begin{abstract}
Abstrak
Salah satu masalah sosial yang diakibatkan oleh teknologi internet adalah akses ke situssitus yang memuat pornografi dan pornoaksi. Sekalipun pemerintah telah melarang dan memblokir situs-situs semacam itu, pada kenyataannya berpeluang ditembus dengan berbagai cara. Pada makalah ini dibuat sistem untuk mencegah akses konten pornografi dengan menggunakan perangkat keras berupa papan ketik yang ditambahi sistem tertanam. Alat ini bekerja dengan mendeteksi kata kunci yang dipakai pengguna untuk melakukan pencarian di browser. Jika terdapat adanya kesamaan antara kata kunci yang dimasukkan pengguna dengan basis data pada sistem tertanam maka akan dilakukan penutupan jendela browser. Basis data bisa diperbarui untuk menambah akurasi deteksi. Proses pencarian dan pencocokan antara kata kunci dengan basis data dilakukan dengan metode sekuensial. Hasil pengujian menunjukkan bahwa sistem dapat bekerja sesuai dengan yang direncanakan, yaitu menutup browser jika pengguna melakukan pencarian dengan kata kunci yang dilarang, serta mampu melakukan pembaruan basis data. Pengujian algoritma sekuensial dengan menggunakan 1200 kata yang ada di basis data, menunjukkan waktu pencocokan antara 32 ms sampai 189 ms. Jika kata tidak ada di basis data, diperlukan 190 ms untuk menyelesaikan pencarian dan pencocokan.
\end{abstract}

Kata kunci: sistem tertanam, pornografi, papan ketik, basis data

\begin{abstract}
One of the social problems caused by internet technology is the access to sites containing pornography and pornographic acts. The government prohibits and blocks sites that provide pornographic services, however, the various blocking methods that are carried out can still be penetrated. To improve the prevention of accessing pornographic content, an embedded system was created in which the filtering of accessing pornographic content was carried out using hardware in the form of a keyboard with an embedded system added. This system works based on the input of keywords by the user which is used to search using
\end{abstract}


the browser. If there is a similarity between the keywords entered by the user and the database in the embedded system, the browser window will be closed. To increase the detection accuracy, the database can be updated. The searching and matching process is carried out using a sequential method. The test results shoed that the embedded system can work as planned, i.e., close the browser and update the database. The sequential algorithm test using 1200 words in the database, shows that in the best conditions the search time is 32 milliseconds, the worst conditions are 189 milliseconds, whereas if the word is not found it will take 190 milliseconds.

Keywords: embedded system, pornography, keyboard, database

\section{Pendahuluan}

Perkembangan internet yang pesat memberikan kenyamanan akses informasi kepada para pengguna dalam kehidupan sehari-hari, sementara di sisi lain, membuat pengguna internet mudah terekspos pada sejumlah konten negatif, misalnya pornografi. Konten pornografi dapat berupa video, gambar, dan teks. Anak-anak dan remaja harus dicegah untuk melihat-lihat konten negatif seperti ini. Remaja yang menggunakan pornografi, terutama yang ditemukan di internet, memiliki derajat integrasi sosial yang lebih rendah, tingkat kenakalan lebih tinggi, gejala depresi yang lebih tinggi, dan penurunan ikatan emosional dengan keluarga. Sementara orang dewasa juga banyak yang menghindari konten pornografi terutama saat berada di tempat kerja. Semua itu telah membuat penyaringan konten pornografi mendapatkan perhatian terus yang meningkat [1][2].

Upaya untuk melakukan penyaringan konten pornografi terus dilakukan. Berbagai metode telah digunakan, antara lain dengan melakukan ekstraksi citra, tekstur dan penyaringan berdasarkan URL [3][4][5][6]. Semua metode tersebut menggunakan perangkat lunak untuk melakukan penyaringan, yang masih berpeluang ditembus.

Maka untuk meningkatkan penyaringan konten pornografi pada makalah ini dibuat solusi menggunakan perangkat keras, berupa sistem tertanam yang dihubungkan dengan papan ketik konvensional. Metode yang digunakan adalah dengan mencocokkan kata kunci yang diketik oleh pengguna dengan basis data kata porno yang terdapat pada sistem tertanam. Apabila pengguna mengetikkan kata yang sama dengan kata yang tersimpan di basis data maka sistem tertanam akan mengirimkan perintah untuk melakukan penutupan browser yang digunakan untuk pengguna berselancar di internet.

\section{Tinjauan Pustaka}

\subsection{Pornografi}

Menurut Undang-Undang No, 44 Tahun 2008 tentang pornograf pasal 1 ayat 1 tertulis yang dimaksud dengan pornografi adalah gambar, sketsa, ilustrasi, foto, tulisan, suara, bunyi, gambar bergerak, animasi, kartun, percakapan, gerak tubuh, atau bentuk pesan lainnya melalui berbagai bentuk media komunikasi dan/atau pertunjukan di muka umum, yang memuat kecabulan atau eksploitasi seksual yang melanggar norma kesusilaan dalam masyarakat [7].

\subsection{Sistem Tertanam}

Saat ini sistem tertanam menggantikan berbagai sistem yang sebelumnya direalisasikan dengan rangkaian elektronik yang kompleks. Biasanya jantung dari sistem yang tertanam adalah mikrokontroler. Salah satu contoh mikrokontroler adalah Arduino. 
Arduino adalah platform prototyping berbasis open source yang digunakan untuk mengontrol perangkat fisik [8].

Sistem tertanam merupakan sistem perangkat keras komputer yang memiliki perangkat lunak yang tertanam di dalamnya. Sistem tertanam dapat menjadi sistem yang berdiri sendiri atau menjadi bagian dari sistem yang lebih besar. Sistem tertanam adalah sistem berbasis mikrokontroler atau mikroprosesor yang dirancang untuk melakukan tugas tertentu [9]. Pada makalah ini sistem tertanam dirancang untuk tugas khusus yaitu untuk melakukan penyaringan kata-kata porno.

\subsection{Arduino [10]}

Arduino adalah platform elektronik yang bersifat open-source berbasis perangkat keras dan perangkat lunak yang mudah digunakan. Papan Arduino dapat membaca masukan mengaktifkan sensor mengaktifkan motor, menyalakan LED, atau mengirimkan informasi secara daring.

Arduino Leonardo adalah papan mikrokontroler berbasis ATmega32u4, memiliki 20 pin input / output digital, osilator kristal $16 \mathrm{MHz}$, koneksi micro USB, header ICSP, dan tombol reset. Arduino Uno adalah papan mikrokontroler berbasis ATmega328P, memiliki 14 pin input / output digital, 6 input analog, resonator keramik $16 \mathrm{MHz}$.

\section{Perancangan Sistem}

Diagram alir untuk mengimplementasikan sistem tertanam dalam mencegah akses pronografi, ditunjukkan pada Gambar 1. Cara kerja perangkat ini adalah sebagai berikut:

1. Sistem tertanam akan menunggu apakah ada masukan dari pengguna.

2. Jika tidak ada masukan, maka sistem tertanam akan kembali menunggu masukan pengguna

3. Jika ada masukan, masukan tersebut akan diperiksa apakah masukan tersebut merupakan karakter enter (pengguna menekan tombol enter).

4. Jika masukan tersebut bukan merupakan karakter enter maka sistem tertanam akan melanjutkan masukan tersebut ke keluaran yang akan diterima komputer.

5. Jika masukan tersebut merupakan karakter enter maka sistem tertanam akan melakukan pencarian dan pencocokan dengan basis data yang ada pada sistem tertanam menggunakan algoritma pencarian sekuensial.

6. Jika tidak terdapat kecocokan dengan basis data, maka karakter enter akan diteruskan ke komputer seperti halnya masukan lainnya dan browser berfungsi seperti biasa.

7. Namun jika didapati kecocokan dengan basis data maka sistem tertanam akan mengeluarkan perintah untuk melakukan penutupan program browser secara paksa. 


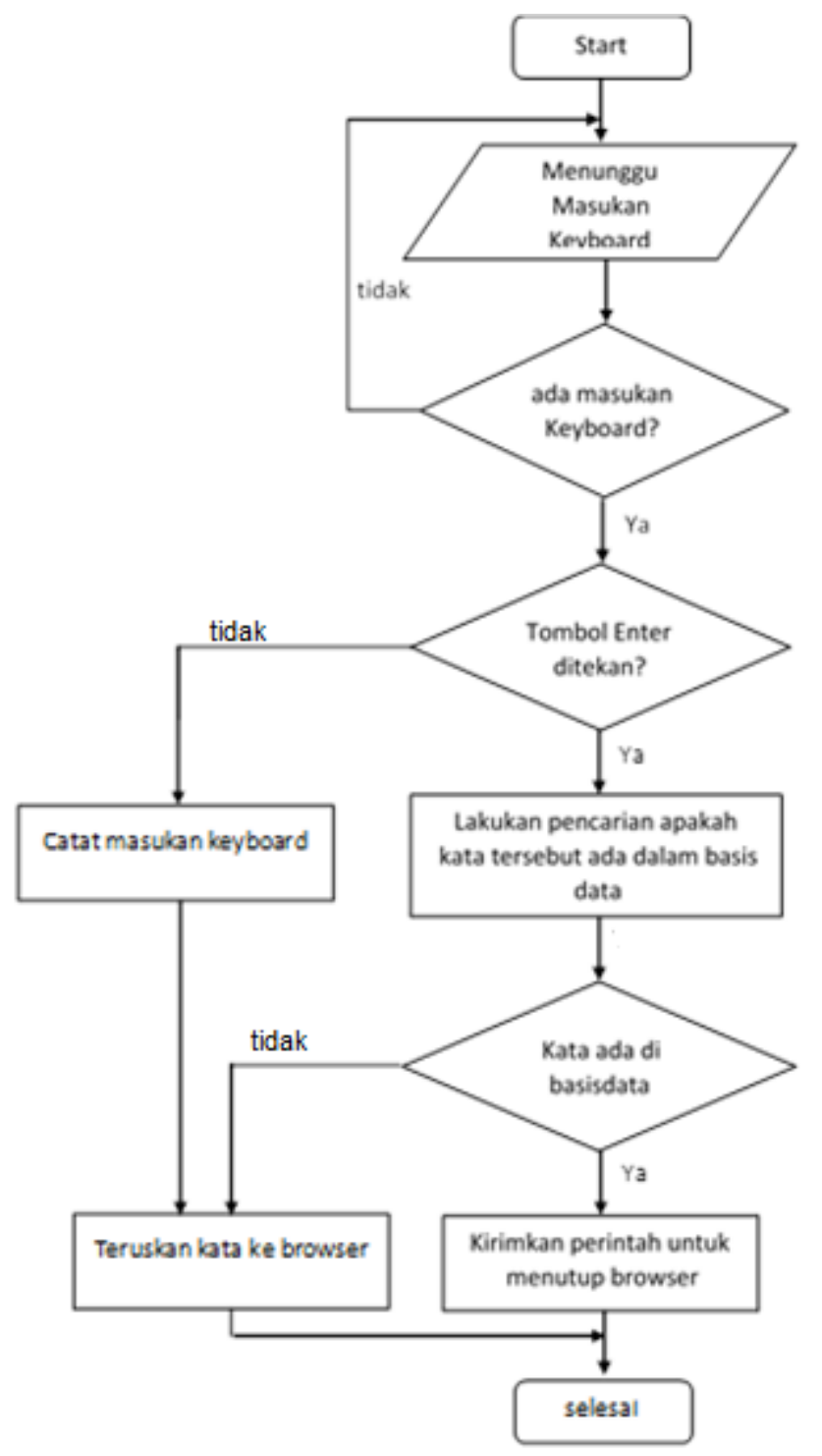

Gambar 1. Diagram alir cara kerja perangkat yang akan dibuat

\subsection{Perancangan dan Realisasi Perangkat Keras}

Proses selanjutnya adalah merealisasikan perangkat keras seperti ditunjukkan pada Gambar 2 - 5 yang merupakan rencana desain dan blok diagram. Rangkaian perancangan perangkat keras, dan desain perangkat keras tampak luar. 
Implementasi Sistem Tertanam Pada Papan Ketik untuk Meningkatkan Penyaringan

Konten Porno Melalui Pencarian Kata pada Browser Bachtiar Lazuardi, Hartanto Kusuma Wardana, Deddy Susilo

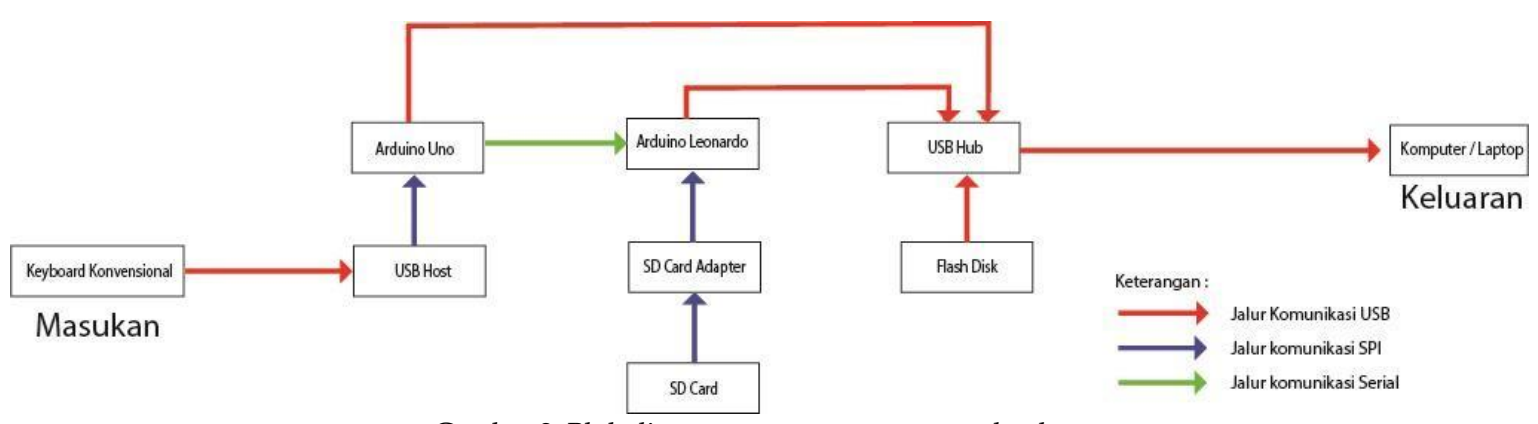

Gambar 2. Blok diagram perancangan perangkat keras

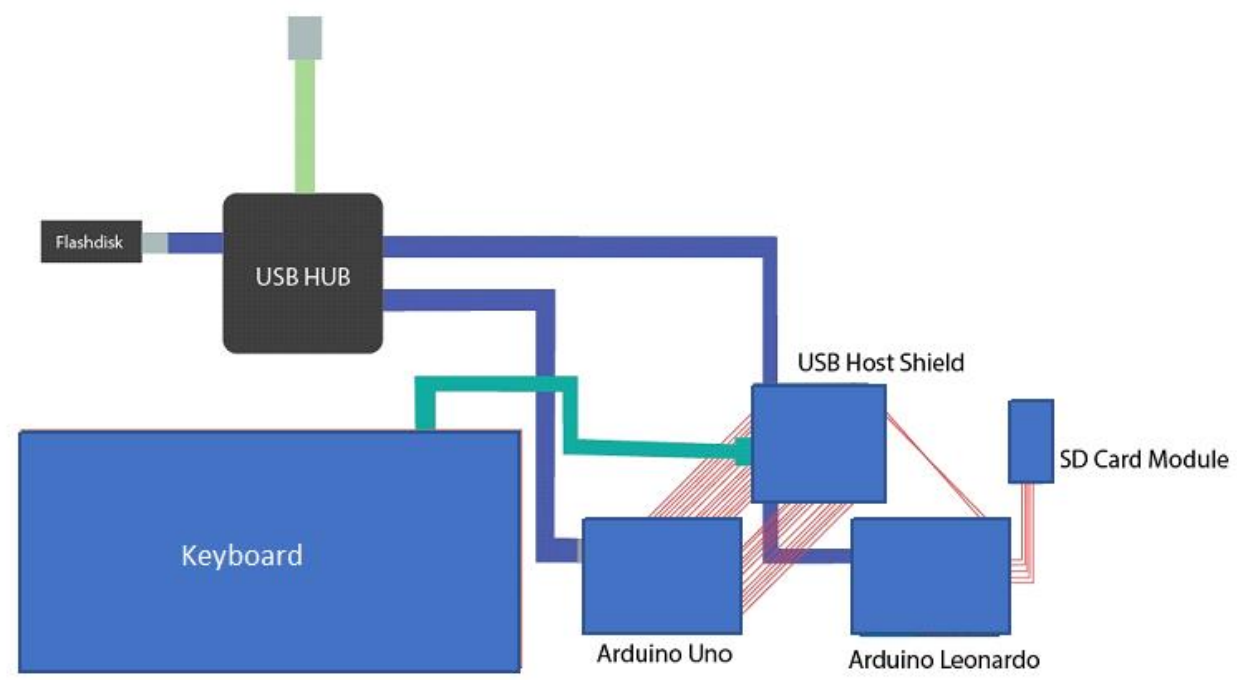

Gambar 3. Gambar perancangan rangkaian perancangan perangkat keras

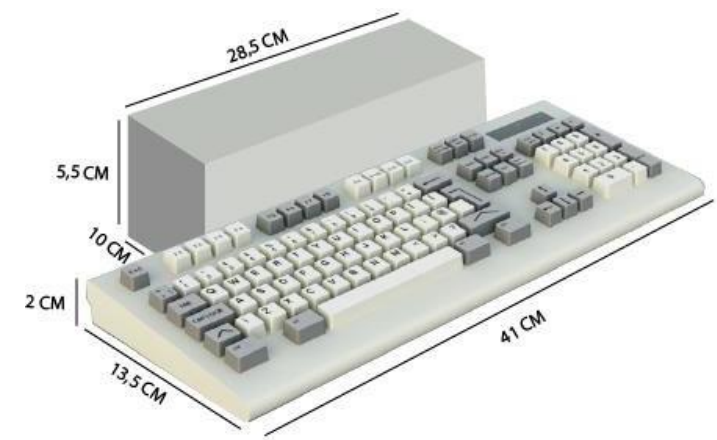

Gambar 4. Gambar perancangan perangkat keras tampak luar 


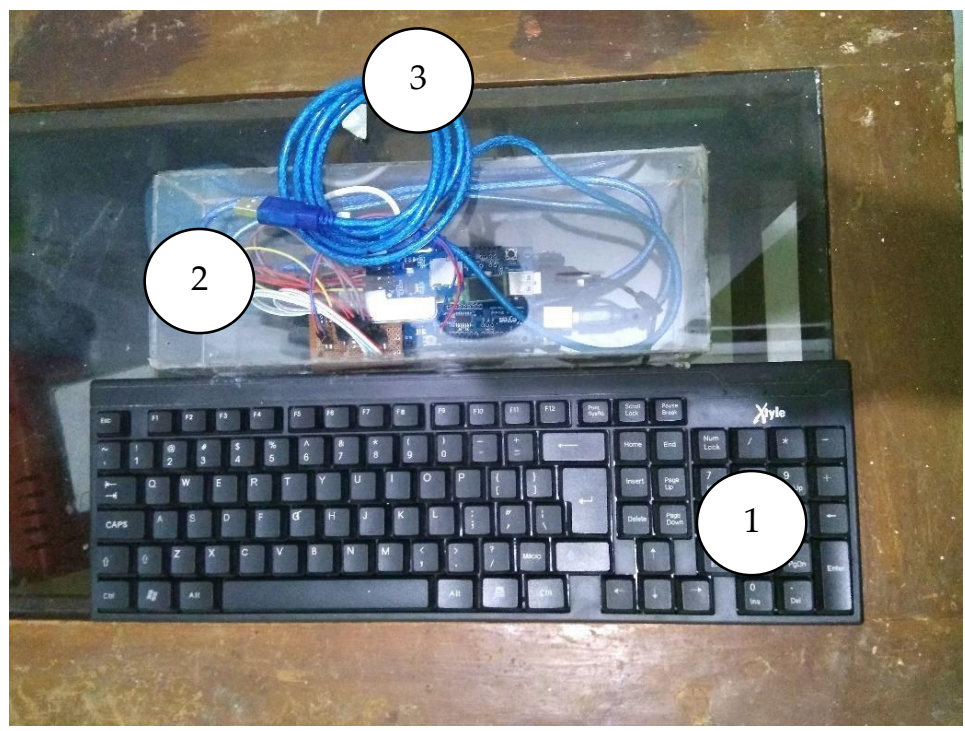

Gambar 5. Gambar realisasi perangkat keras

Gambar 5 menunjukkan hasil rancangan yang sudah direalisasikan, terdiri dari keyboard (1), sistem tertanam (2) dan kabel yang menghubungkan sistem tertanam ke perangkat komputer (3). Keyboard akan dihubungkan ke sistem tertanam yang berfungsi sebagai penyaring kata yang diketikkan oleh pengguna.

Sistem yang dibuat terdiri dari dua bagian yaitu bagian perangkat keras dan perangkat lunak. Perangkat keras utama yang digunakan adalah dua mikrokontroler yaitu, Arduino Uno dan Arduino Leonardo. Kedua mikrokontroler ini dipilih dengan pertimbangan sebagai berikut:

a. Arduino Uno mempunyai lebih dari 1 port SPI namun tidak dapat mengakses bagian port USB pada komputer atau laptop secara langsung sehingga membutuhkan perangkat lunak pihak ketiga. Arduino Leonardo dapat mengakses port USB komputer atau laptop secara langsung, namun hanya mempunyai satu port SPI sehingga saat dihuhungkan dengan perangkat USB host dengan IC MAX3421E dan SD card adapter tidak dapat bekerja dengan baik.

b. Kemudahan mendapatkan mikrokontroler tersebut dipasaran karena kedua mikrokontroler ini sebagai komponen utama perangkat keras yang akan dibuat.

Perangkat lunak utama menggunakan algoritma sekuensial [11] yang digunakan untuk melakukan pencarian dan pengecekan pada kata yang dimasukkan oleh pengguna. Pemilihan algoritma sekuensial didasarkan pada kemudahan dalam implementasi algoritma tersebut ke sistem yang akan dibuat, dan akurasinya tinggi.

\subsection{Perancangan Perangkat Lunak}

Perangkat lunak yang akan dibuat ditunjukkan dalam Gambar 6. 
Implementasi Sistem Tertanam Pada Papan Ketik untuk Meningkatkan Penyaringan

Konten Porno Melalui Pencarian Kata pada Browser Bachtiar Lazuardi, Hartanto Kusuma Wardana, Deddy Susilo

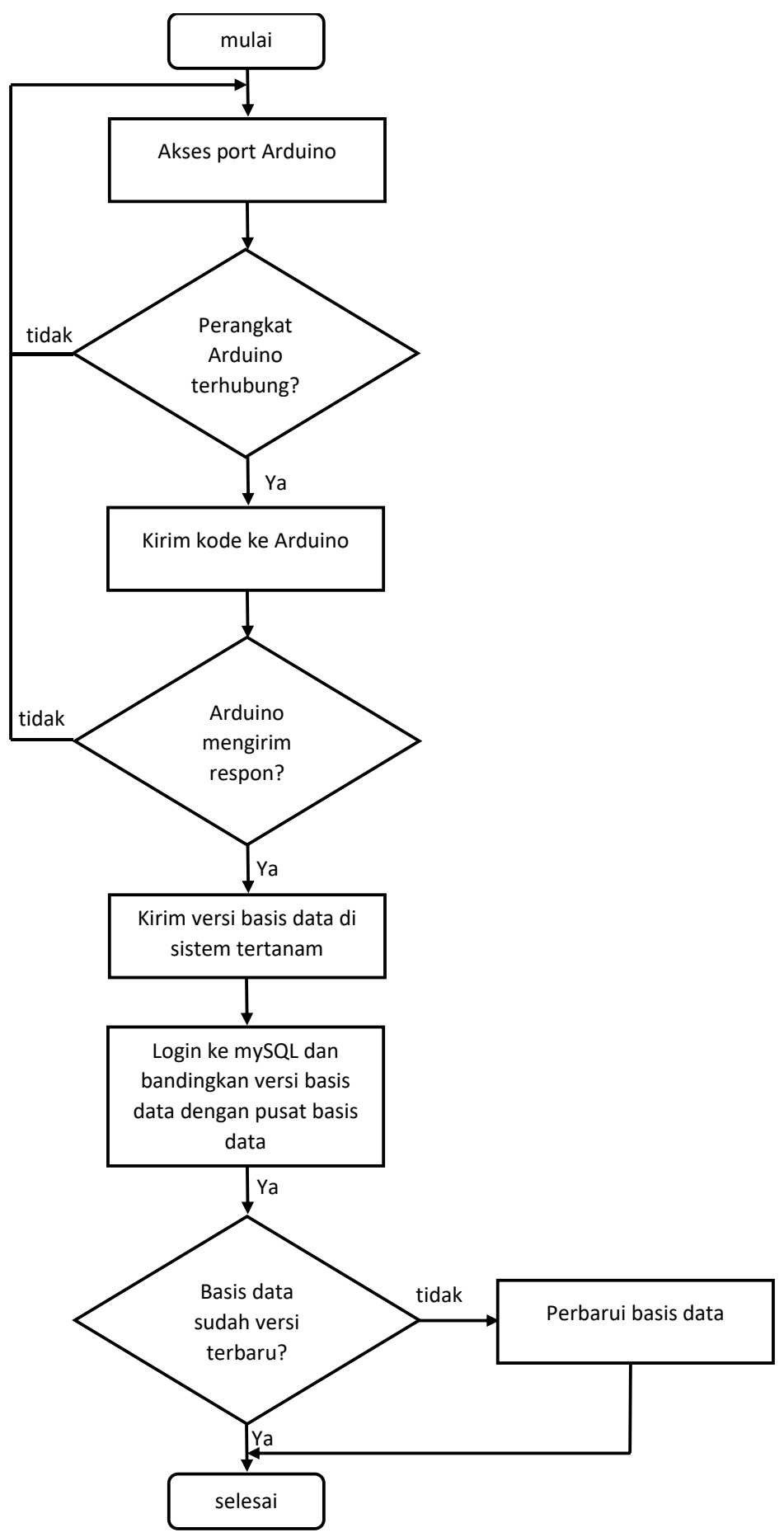

Gambar 6. Diagram alir cara kerja pembaruan basis data pada program tambahan

Cara kerja perangkat ini adalah sebagai berikut :

1. Mengakses port Arduino Leonardo

2. Jika tidak terdapat port Arduino Leonardo yang dapat diakses maka program akan berhenti. 
3. Jika terdapat port Arduino Leonardo yang dapat diakses maka program akan mengirim kode tertentu pada Arduino tersebut.

4. Selanjutnya jika terdapat respon yang diinginkan, maka akan dilakukan pengecekan versi basis data. Jika tidak terdapat respon yang diinginkan maka program akan kembali mengakses port Arduino Leonardo yang terdeteksi.

5. Program akan mengirim kode untuk mengetahui versi basis data pada sistem tertanam

6. Program akan menerima versi basis data dari sistem tertanam.

7. Melakukan login ke server MySQL dan memilih kode basis data terbaru.

8. Program akan melakukan pembandingan versi basis data sistem tertanam dengan versi basis data pada server MySQL.

9. Jika mendapati telah versi terbaru maka program akan berhenti.

10. Jika tidak maka program akan mengakses tabel basis data terbaru sesuai urutan abjad.

11. Program melakukan pengecekan untuk mengetahui akhir dari tabel basis data.

12. Jika telah didapati pada tabel terakhir maka program akan mengirim kode penghentian dan mengirimkan konfirmasi pembaruan basis data.

13. Jika tidak maka program akan mengirimkan kata kunci dan menunggu respon arduino selesai mengolah data.

14. Jika telah mendapat respon konfirmasi kata kunci telah ditulis pada SD Card maka program akan melakukan pengecekan akhir record. Jika belum mencapai akhir record maka akan mengirim kata kunci selanjutnya.

15. Jika telah pada akhir record maka program akan mengirim kode konfirmasi ke arduino dan berpindah pada tabel selanjutnya.

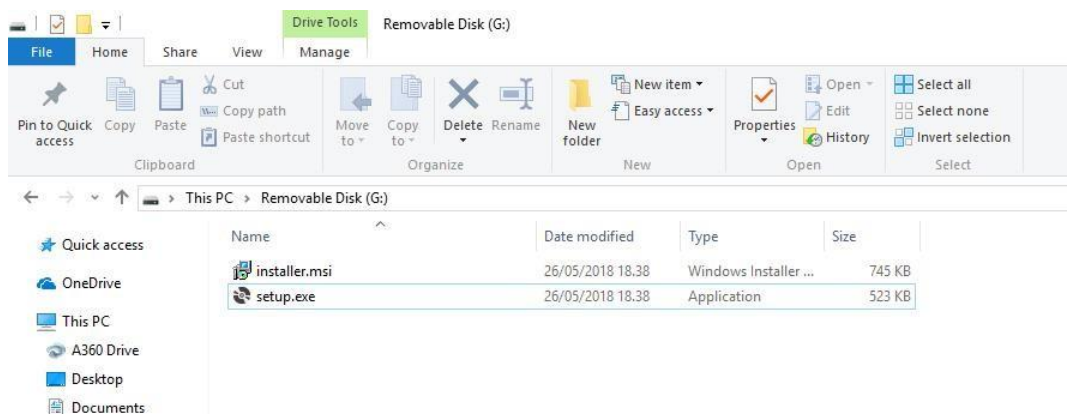

Gambar 7. Installer hasil dari perancangan

Hasil rancangan pada Gambar 6, adalah perangkat lunak terkompilasi dengan format *.exe. seperti yang ditunjukkan pada Gambar 7. Format tersebut dipilih karena merupakan format perangkat lunak untuk sistem operasi Windows sehingga pengguna dapat melakukan pemasangan program tersebut ke dalam komputer dengan mudah. 
Implementasi Sistem Tertanam Pada Papan Ketik untuk Meningkatkan Penyaringan

Konten Porno Melalui Pencarian Kata pada Browser Bachtiar Lazuardi, Hartanto Kusuma Wardana, Deddy Susilo

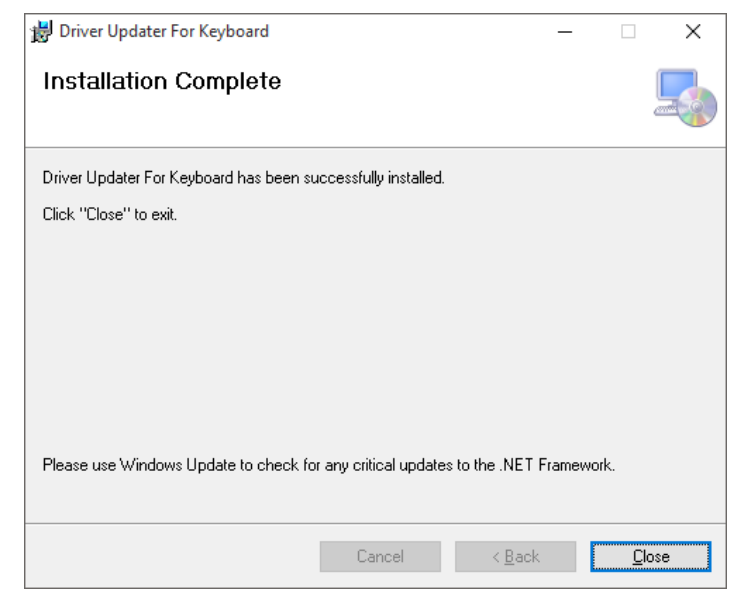

Gambar 8. Perangkat lunak berhasil dipasang

Perangkat lunak terkompilasi dengan format *.exe selanjutnya dipasang di perangkat komputer dengan sistem operasi Windows. Gambar 8 menunjukkan notifikasi jika perangkat lunak berhasil dipasang.

\subsection{Tampilan Antarmuka Pengguna}

Program yang telah terpasang pada komputer pengguna dan telah aktif, akan melakukan pemeriksaan untuk pembaruan basis data, seperti ditunjukkan Gambar 9.

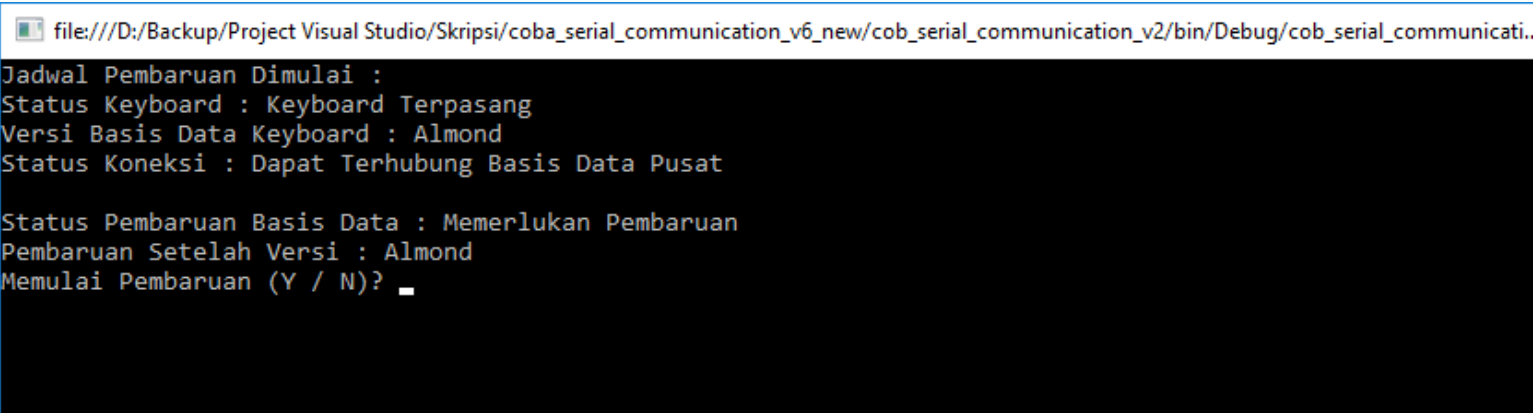

Gambar 9. Tampilan perangkat lunak jika tersedia pembaruan basis data

Jika terdapat pembaruan maka program akan memberikan pemberitahuan kepada pengguna bahwa tersedia pembaruan basis data. Jika pengguna setuju melakukan pembaruan maka program akan memulai proses pembaruan tersebut.

\section{Pengujian dan Analisis}

\subsection{Pengujian Pembaruan Basis Data Pada Sistem Tertanam}

Untuk meningkatkan kemampuan deteksi, maka database sistem tertanam harus diperbaharui dari waktu ke waktu. Gambar 10 menunjukkan database sistem tertanam sebelum dilakukan pembaruan dan Gambar 11 menunjukkan database sistem tertanam setelah dilakukan pembaruan. 


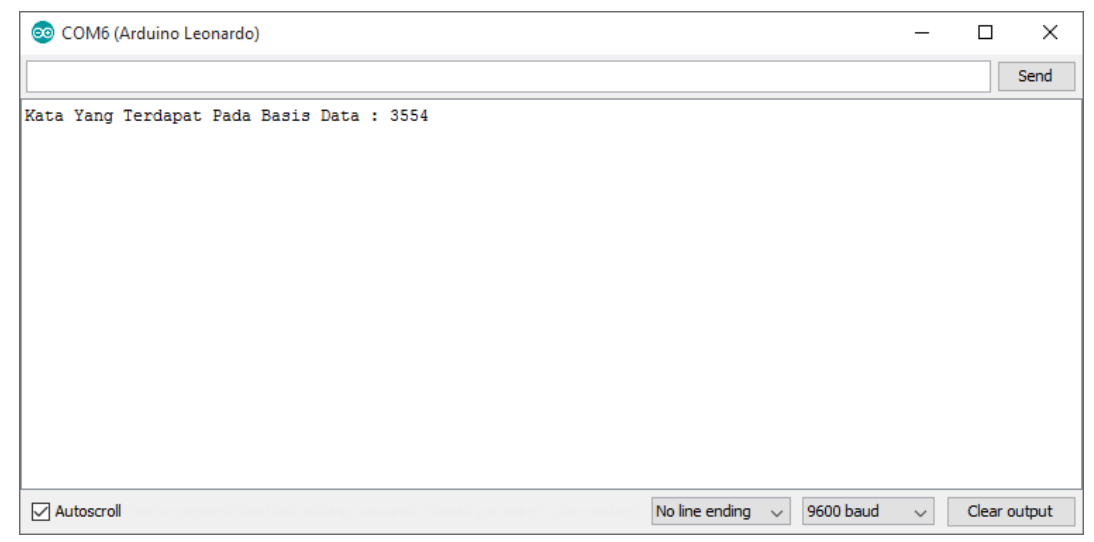

Gambar 10. Gambar hasil perhitungan kata sebelum dilakukan pembaruan

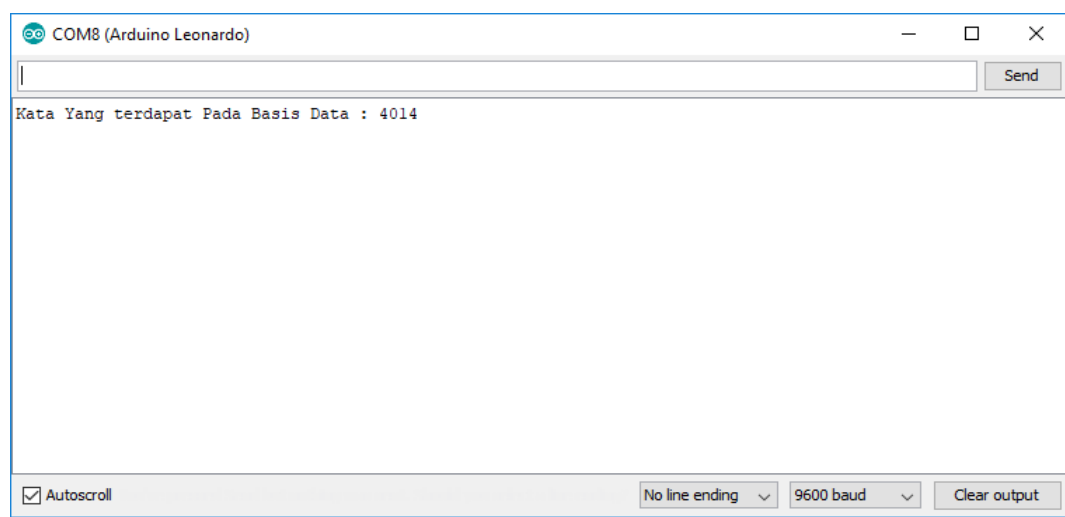

Gambar 11. Gambar hasil perhitungan kata setelah dilakukan pembaruan

Pengujian pembaruan basis data pada sistem tertanam telah dilakukan sebanyak 10 kali dengan penambahan kata secara bertahap,ditunjukan pada Tabel 1 dengan persentase keberhasilan $100 \%$.

Tabel.1 Pengujian pembaruan basis data

\begin{tabular}{|l|c|c|}
\hline No & Jumlah Kata & Persentase Keberhasilan \\
\hline 1 & 700 & $100 \%$ \\
\hline 2 & 750 & $100 \%$ \\
\hline 3 & 800 & $100 \%$ \\
\hline 4 & 850 & $100 \%$ \\
\hline 5 & 900 & $100 \%$ \\
\hline 6 & 950 & $100 \%$ \\
\hline 7 & 1000 & $100 \%$ \\
\hline 8 & 1050 & $100 \%$ \\
\hline 9 & 1100 & $100 \%$ \\
\hline 10 & 1150 & $100 \%$ \\
\hline
\end{tabular}

\subsection{Penutupan Browser}

Pengujian menutup browser chrome dan opera mini dilakukan dengan mengirimkan perintah berupa penekanan papan ketik pada tombol pintasan untuk membuka command prompt lalu mengirimkan perintah berupa taskkill. Kode fungsi penutupan browser ditunjukkan pada Gambar 12. 
1. void killing_browser() \{

2. Keyboard.press(KEY_LEFT_GUI);

3. Keyboard.press(' $r$ ');

4. delay(1);

5. Keyboard.releaseAll();

6. delay(50);

7. Keyboard.print("taskkill /f /im chrome.exe /im opera.exe");

8. Keyboard.write(KEY_RETURN);

9. $\}$

Gambar 12. Fungsi menutup browser

\subsection{Kecepatan Penyaringan Kata}

Pengujian Kecepatan penyaringan kata ditunjukkan di tabel 2. dengan menggunakan algoritma sekuensial, dilakukan dengan kondisi terbaik, yaitu saat kata yang dicari berada pada posisi pertama di basis data. Kondisi terburuk yaitu saat kata yang dicari berada di posisi terakhir basis data. Dilakukan juga pengujian dengan mencari kata yang tidak terdapat di basis data.

Tabel 2. Pengujian kecepatan penyaringan kata

\begin{tabular}{|c|c|c|}
\hline Kondisi & Jumlah Kata & Waktu (ms) \\
\hline Terbaik & 1200 & 32 \\
\hline Terburuk & 1200 & 189 \\
\hline Kata tidak ditemukan & 1200 & 190 \\
\hline
\end{tabular}

\section{Kesimpulan}

Dari pengujian dan analisis yang telah dilakukan dapat diambil kesimpulan bahwa perangkat lunak pendukung sistem tertanam berhasil dipasang dan bekerja sesuai dengan perancangan. Pembaruan basis data mikrokontroler melalui jalur komunikasi serial dapat dilakukan. Browser Chrome dan Opera Mini berhasil menutup saat terdeteksi kesamaan antara basis data dengan kata yang diketikkan oleh pengguna di keyboard. Pengujian pencarian kata dengan menggunakan algoritma sekuensial membutuhkan dengan waktu yang cukup singkat yaitu maksimal 190ms.

\section{Daftar Pustaka}

[1] C. X. Ries and R. Lienhart, "A survey on visual adult image recognition," Multimedia tools and applications, vol. 69, no. 3, pp. 661-688, 2014

[2] W. O. Eric, J. B. Richard, C. M. Jill, and C. R. Rory, "The impact of internet pornography on adolescents: A review of the research." Sexual Addiction $\mathcal{E}$ Compulsivity, vol. 19, pp. 99-122, 2021.

[3] F. A. Tsani, I. Riadi, dan A. Fadlil, Deteksi konten porno pada akun twitter melalui nipple detection. Proceeding Seminar Nasional Informatika (SEMNASIF), vol 1, no 1., 2018

[4] A. N. Hanung, R. Fauziazzuhry, B. A. Teguh, K. Z. O. Widhia, dan L. B. B. Ratna, "Texture analysis for skin classification in pornography content filtering based on support vector machine," J. Eng. Technol. Sci., vol. 48, no. 5, pp. 584-596, 2016. 
[5] A. T. El-Hafeez, M. Tarek, and O. Ahmed. "An efficient system for blocking pornography websites," 2014. doi:10.4018/978-1-4666-6030-4.ch008.

[6] M. Hussain, et al.., "Towards ontology-based multilingual URL filtering: A big data problem," The Journal of Supercomputing, vol. 74, 2018. doi: 10.1007/s11227-018-2338-1.

[7] Undang-undang no 44 Tahun 2008 tentang Pornografi, Jakarta, 2008

[8] N. F. Voudoukis, "Arduino based embedded systems and remote access technologies of environmental variables monitoring," European Journal of Electrical and Computer Engineering, vol. 3, no.4, July 2019.

[9] P. Marwedel, "Embedded system design embedded systems, foundations of cyberphysical systems, and the Internet of Things," 3th Edition, Springer International Publishing AG, 2018.

[10] J. Blum, "Exploring arduino, tools and techniques for engineering wizardry," $2^{\text {nd }}$ ed., John Wiley \& Sons, Inc, 2020.

[11] S. Anisy dan S. Mayang, "Implementasi algoritma sequential searching untuk pencarian nomor surat pada sistem arsip elektronik," Jurnal Pseudocode, vol. 5, no. 1, Februari 2018. 